\title{
Panic Learning off (and on) the Covid Campus
}

\author{
Tara Brabazon, Jamie S. Quinton, Narelle Hunter
}

\section{Told You So. By Way of Introduction. (Tara)}

I am a five-foot two Australian woman working in the humanities. I am accustomed to be ignored, mansplained, marginalized or described as 'wrong' or 'too theoretical' or 'naïve' in multiple languages. But on this singular occasion, my predictions were correct. Completely and saturatingly correct.

My first full-time academic post was in 1994, in Aotearoa / New Zealand. Large lecture theatres. Huge student cohorts. I was a junior, contract staff member that fulfilled the housework functions of a traditional, conservative history department. Moving through a series of contract roles, I was tenured by 1998 as I started to teach online classes in addition to on-campus and distance education modes. As early adopters of e-learning, my colleagues and I were left angry, manipulated, deceived and exploited, enduring third-rate learning management systems, incompetent 'leadership' decisions about teaching and learning, no funding and ridiculous timelines. It was dreadful. The entire e-learning movement at this time can be captured by a t-shirt slogan andragogy: "get it online." The 'it' is important to identify. 'It' was content. No time nor expertise were given to explore the relationship between form and content, ponder interface management and multimodality, universal design, deficit models of teaching and learning, the availability of hardware and software in regional, rural and remote locations, or the information literacy of academics or students. "Get it online" was the crow call. Because of a lack of professional development, this strategy failed. Compliance dominated. In the rush to 'get it online,' study guides and syllabi were saved to PDF and uploaded. Live lectures were recorded and posted online. Substandard content began filling and clogging learning management systems without carefully developed born-digital objects. Poor lectures - and poor lecturers - were revealed, amplified and enhanced through this process. Academics had not complied. They had not innovated. Instead, their lectures were automatically recorded and their study guides were digitized. This was the online learning revolution that never happened.

I was angry. I am still angry. As an Australian woman working in the humanities, anger is my primary socialization. It then translates into rage, frustration and bitterness. I am an academic that - alongside my disciplinary expertise - also completed Bachelor and Master's degrees in Education. To this day, it amazes me that academics teach without any formal learning in how to do so. Certainly, some lunchtime seminars or a graduate certificate sands off the roughest of edges of incompetence. But the construction of curriculum, backward mapping, multimodal materials that activate diverse approaches to learning outcomes for diverse student cohorts, require more learning and professional development than is possible through a session on "how to create a rubric." 
I was so angry that fury bubbled out of my classrooms and online learning fora and onto the page. My first two monographs were relatively normal in topic and theoretical frame for a cultural studies academic. Tracking the Jack (2000) investigated the diverse colonization histories of Australia and New Zealand. Ladies who Lunge (2002) summoned feminist popular cultural studies. But the third book was cooked by rage. Digital Hemlock: Internet Education and the Poisoning of teaching was as pointed as the title suggests. Fuelled by Socratic idealism, I expressed the scale of the online learning disaster. The incompetence. The waste of money. The lack of learning. Inspired by Stanley Aronowitz's The Knowledge Factory (2000), I also signified the changes to the university workforce through casualized online education. This book was shortlisted for a writing award, picked up some citations, and the title has continued to circulate. An array of keynote addresses and articles followed and the titles indicated the hypocrisy in the content: "We've spent too much money to turn back now" (Brabazon, 2011).

After Digital Hemlock, online teaching and learning became more diabolical, underfunded and oversold. Indeed university 'managers' gave up on academics who they had not bothered to train or scaffold through professional development. A new group emerged in our institutions: "educational designers." This invented profession would take 'content' and - you are ahead of me, dear reader - "get it online." The loss of expertise - or disciplinary literacy if we summon this provocative and important phrase - was profound. Concurrently, the library profession was losing its credibility and position at the very moment that information literacy had never been more important. From this context - with the arrival and popularity of Google, Wikipedia and the grandfather interfaces of social media - The University of Google was published (Brabazon, 2008). Anti-intellectualism and a disrespect and denial of reading and writing were added to the critique. The lack of learning in e-learning was summoned with horror, anger and disgust.

Although my rage was not intended to manifest into a trilogy, Digital Dieting (2013) was my Return of the Jedi. Dark, resolute, melancholic, and meaningful, this book was written in temporary accommodation amidst a volatile moment of my career where I worked in three universities in three different countries over a three-year period. This personal and professional horror movie pounded with the dull thud of the mediocrity and incompetence in university leadership structures. As the Global Financial Crisis revealed the failures of neoliberalism in the rest of the economy, it remained the blood of higher education. Quality assurance replaced quality. Compliance replaced excellence. Teaching was the housework of the university, completed by women, the precariat workforce, and those who rarely attracted large grants for their research.

Through this trilogy, the untheorized, underprepared drumbeat of online learning was documented. With students becoming consumers, buying their degrees, rubrics automated assessment. But questions of 'value' and the 'services' being delivered for those fees remained in question. The movement to online learning was convenient and efficient for the delivery of content, but the scope and scale of the learning enabled was much more ambivalently constituted and evaluated. With the movement to rapid, panic learning through COVID-19, the 'choice' of face-to-face delivery was removed. Online learning was cut-price content delivery, enabled by casual, cut-price academics (Farrelly 2020). What this personal, professional and research narrative introduces is the two decades of 'getting content online' without attention to the professional development of staff, attention to the hard work required to develop authentic borndigital objects, the funding required for infrastructure, and clear and research-driven evaluative protocols required to assess effectiveness. The history of online learning in our universities is defined by a lack, an absence, a marginalization, a void. From this history, COVID-19 entered our campuses, portals, and platforms.

\section{The University of Disaster (Where Tara Updates Virilio with Less Christianity and More Zombie Foreboding)}

The COVID-19 pandemic has shattered international higher education like a crazed window pane. With movement restricted and then stopped through the first few months of 2020, 
academic and administrative staff rushed to convert face-to-face lectures, tutorials and laboratory classes to a screen-based environment. Scholars probed whether universities were ready for this rush to digitized education (Houlden and Veletsianos, 2020). Significantly, this concern was expressed by Houlden and Veletsianos in The Conversation. The thousands of refereed articles and scholarly monographs probing the flawed history of online learning were ignored. Instead, academic journalism restated the obvious. As I argued in the first section of this article, online learning has been in crisis for two decades. Digitization has been over-sold and under-used. Inexperienced and underdisciplined students have been medicated by online learning to hide their lack of skill, information literacy, or commitment.

With the onset of COVID-19, universities in crisis only had one option: panic learning. With the loss of international students - and the revenue that they bring - the change to online environments had to be introduced at speed, throughout all disciplines and with no funding to enable the expeditious implementation. Indeed, this accelerated movement to online learning was a desperate act for institutions, rendering redundant many of their staff because of severe financial hardship. Already weak universities, located in regional environments, were most impacted (Henebery 2020).

To summon the word 'postmodernism' in a university is the equivalent of saying 'herpes' outside of it. One of the great tragedies in the history of the humanities, particularly when it is tangled with the history of higher education after the Second World War, is how complex ideas are labeled, demeaned and dismissed because they do not slot into a specific model or mode of funded research that is 'industry ready,' impactful, and easily understood. 'Postmodernism' became the rubbish bin for difficult ideas that required complex and specialist reading, often in languages other than English, and attacked the easy hierarchies assembled by white English and American humanities scholars who attended specific universities, published in particular journals and served as defiant - if ignorant - gatekeepers of the disciplines. Meanwhile, 'theory' and 'theorists' have become marginalized in favor of the empirical and empiricist.

The clustering denial of complex ideas and the labeling of the difficulties have left universities historically unprepared to manage myriad critiques from indigenous communities, citizens of color, the widening participation agenda, and multiple layers of government. Floating through the market economy without a vision or purpose, universities were not ready to manage changes to teaching and learning, a loss of funding streams from international students (Marshman and Larkins 2020), or the shredding of public finances to pay for shutdowns, lockdowns or a global health crisis.

If the humanities and theoretical social sciences had maintained a stronger profile and intellectual spine, their impact in criminology, media studies, cultural studies, socio-legal studies, politics, architecture and leisure studies would have moved more effectively to other disciplines (Redhead, 2004a, 2004b, 2008, 2013). However, what is important, and recognized by Smith, Clarke, and Doel after the Global Financial Crisis, is that although postmodernism was an intellectual bin for those who read too little and speak too much, Baudrillard's research survived this label (Smith, Clarke and Doel 2011: 326). Therefore, the capacity for Virilio to be reconfigured after his death was ripe and ready. Virilio was more than a scholar of speed, just as Baudrillard was never a 'denier' of the Gulf War. Instead, we re-activate the theorist of the bunker (Virilio 2009c), the accident, the disaster, and the oblique. He remains a provocative and infuriating intellectual of the extremes (Gane, 1991, Redhead, 2011, Coulter, 2012). If COVID needs a theorist - which it does - then the claustropolitan university has found its intellectual guide in Paul Virilio.

Virilio was a theorist of endings or, to use his word, "finitude." The Aesthetics of Disappearance (2009a) and Grey Ecology (2009b) all fed into Virilio's conceptualization of the University of Disaster. L'Adminstration de La Peur was published in 2010, later translated as The Administration of Fear (Virilio and Richard, 2012). Climate change was his focus. His short books continued with Le Grand Accelerateur, translated into English as The Great Accelerator (Virilio, 2012). The Global Financial Crisis was the focus of one essay in his collection, with 
another pondering the death of a private life, and the third pondering the Large Hadron Collider at CERN, noting the risks of these experiments on humanity. He probed if CERN had a right to create a black hole (2012, 85-88). What Virilio affirmed, particularly after Baudrillard's death, was his separation from French intellectual culture. His social distancing was of an intellectual kind. He constructed and claimed a defiant space. A gap. A separation. An intellectual bunker. Hauntology. The ghosts of the failures of online learning congealed around the COVID campus.

To explore and grasp the COVID campus, Paul Virilio remains the scholar of record. The University of Disaster (2010) is the argument that frames and shapes our experience, expertise, and trajectory. He confirms "the sense of insecurity" $(2010,4)$ and the "acceleration of "realism"" $(2010,4)$. But further, he presciently demonstrates the role of COVID in our present: "the accident that now replaces all events" $(2010,4)$. The present is uninhabitable, managing the weight and incompetence of anachronisms, dodging the un(der)funded, and unstable promises of a utopic future of the fourth industrial revolution, portfolio careers, and the gig economy. Standardization - and perhaps even standards - have been replaced by the "synchronisation of sensations that are likely to suddenly influence our decisions" $(2010,6)$. This is panic learning. Standards, assessment, expectations, and quality assurance scatter in a frightening and frightened attack on the now. Education, teaching, learning, development - all the predictable trails and pathways to definitive and clear outcomes - are lost.

You can't stop progress, they used to say. No, but today it has stopped all by itself, at the edge of the void, of an interplanetary abyss that puts the finishing touches on the finiteness of a geophysical materiality that once, not so long ago, supported our vitality (Virilio 2010,132)

This dromoscopy - the destructive impact of speed on life, identity, time and our future - is a potent Virilian trope. There is no separation of day and night. The pixilated screen burns time, memory, priorities, and the differentiation of work and leisure. Digitization burns priorities, cracks hierarchies, and destroys the expectations of paid employment and family life.

Reading Virilio's monographs from the 2000s is the closest many researchers will ever get to taking hallucinogens. As he aged, the books became smaller and more intense, like a bitter expresso occupying the extremes of our palate. The University of Disaster is a monograph that has finally found its time. Importantly, when entering the next two sections of this article, Virilio's critique of 'Big Science' - or how he writes it, BIG SCIENCE - is edgy, terrific, and terrifying. The consequences of digitization and accelerated knowledge on the university are presented with their full dystopic flair in this book. Describing the university as "a hospice of science" $(2010,117)$, his fear - not of science but of the unchecked propulsion of crack-fuelled empiricism and progressivism - is starkly dissonant with the mantras, platitudes and desires to 'believe the science.'

Arrogant to the point of insanity, BIG SCIENCE has become powerless to check the excess of its success. This is not so much because of any lack of knowledge as because of the outrageousness, the sheer hubris of a headlong rush without the slightest concern for covering the rear; its incredible ethical and philosophical deficit ... This is where the paradoxical project of radically reforming the university comes in, using as an excuse the failure of the growing success of BIG SCIENCE ... It would mean official inauguration of this UNIVERSITY OF DISASTER, which would constitute the indispensable MEA CULPA now essential to the credibility of a knowledge in the throes of becoming completely suicidal (2010, 118-119)

The evangelical commitment to science, like all evangelical commitments, will not end well. The 'ethical and philosophical deficit' is voided from the politicized binarized times, where 'believing the science' is the whimpering cry to counter the alt-right.

Virilio had one more thought bomb to throw onto our COVID campus. Not surprisingly, it involved not online learning, but online 'training.' 
Let's now take a closer look at this 'society of accelerating realism' as it goes into training. Ours is not yet a completely on-line society, but one where entering the virtual community is compulsory, or very nearly, and this means living in a surrogate reality that deprives us of the tactility, the physical contact and the empathy essential to communal intersubjectivity $(2010,78)$.

Virilio does not summon a pleasantly imagined community. Instead, this university at the end of the world is devoid of humanity, depth, and connection. This is a virus of a different kind. COVID-19 will kill millions of people. Arising as pneumonia on December 31, 2019 in Wuhan China and reported by the Wuhan City Health Committee (2019), it was spread through individuals via touch and transfer of fluids. With no vaccine, the phrase "social distancing" was used as a social medication. Institutions started to close. Businesses and workplaces attempted to continue to operate online with staff working from home. Schools and universities moved online as campuses and institutions entered a period of 'lockdown.' What was seen to be conventional or face-to-face learning ceased abruptly. Quarantined life and education had profound consequences for students, teachers, and learning, including the appearance of mental health concerns (Pragholapati 2020). Travel restrictions were put in place for 90 countries and the vast majority of them rapidly closed their borders. The everyday life of urbanity and rurality was disrupted. Everyday, learning was disrupted. Therefore, the next two sections of this article enter classrooms at the end of the world. This article is written by three researchers who have won teaching awards for innovation and excellence. Yet, in a time of mediocrity, compliance, and panic, what does teaching and learning in a university actually mean? Therefore, we enter a different rendition of Virilio's BIG SCIENCE. We enter the first-year classrooms of Biology and Physics to see the rendering of panic learning in higher education.

\section{Panic Learning in Biology (Narelle)}

\section{Before COVID-19}

2020 began as any other academic year in Australia. Students flocked to campus eager to learn and join the campus community, engaging in a range of orientation activities designed to build the student community and connection to the institution and staff. As one of two academic staff responsible for the first-year core Biology unit, I began teaching a cohort of 860 first-year students in lectures, practicals and tutorials. Natural curiosity arose around rumors of a never before seen virus originating from China. Students were asking when we would get to talk about viruses and asked if I could use this as an example to explain what they saw on the nightly news. I assured them they would learn about viruses in a few weeks.

Lecture theatres were brimming with students, to the point I had to ask them to move from the stairways. Students were engaged with the content, huddling in groups to consider the problems I gave them and happy to catch the tossable microphone to answer my questions. Practicals were abuzz, with 100 students per lab investigating scientific methods by seeing how many of their peers could squeeze into a hula hoop, or if the circumference of their hands was equal to their height. They were learning to use specialized technical equipment such as micropipettes and spectrophotometers to measure the permeability of a cell membrane that they had been learning about in lectures. Tutorials were vibrant and reassuring, with small groups working on tricky concepts, supported by second- and third-year peers. The atmosphere amongst staff and students was overwhelmingly positive. Students who commented that they were initially nervous about attending were finding the environment on campus supportive and welcoming. Just two weeks into the unit, fears of not being able to cope were replaced with confidence and enthusiasm.

As the third week of the semester began, a change was felt in the atmosphere across Australia. Fear returned because of the reality of COVID-19. This fear was real and no-longer just impacting our distant neighbors. It was now on our own soil. On Monday $16^{\text {th }}$ March 2020, I delivered 
my last live lecture to a theatre less than half full. On Tuesday $17^{\text {th }}$ March 2020, I taught my last practical and tutorials ceased. My co-coordinator and I made the decision to cease face-to-face delivery and put the physical and mental health of our students first. This was not a difficult decision to make. We value our students. Their health and well-being are paramount. What was to come was the most challenging week that I have ever experienced in my 18 years of teaching.

\section{Responding to COVID-19}

The decision to stop face-to-face teaching in first-year Biology was made quickly. In a laboratory of 100 students, with 4 casual academic teaching staff as well as me, the fear was palpable. When my co-coordinator approached me with the suggestion to suspend teaching that day, a sense of relief washed over me. Our decision was justified when the following day the Prime Minister, Scott Morrison announced that all public gatherings of more than 100 people were banned. Instead of presenting an interactive lecture in person, tossing a microphone to the audience, that night, I recorded my first virtual interactive lecture. At each point where I would expect students to work together and problem solve, I built-in questions to my virtual presentation. Students would check their understanding as the lecture progressed, pausing and answering the questions within the virtual lecture (presented as a SCORM package in the Moodle-based LMS). The first iteration was not perfect. The sound was too low as my children slept not far away. But the next lecture improved based on student feedback. I moved to a different space and focused on connecting with my students. We had previously used my dog as an example in face-to-face lectures, providing context for the interactive case studies presented in lectures. They would see my puppy in still images as we discussed the bacteria present in a dog's saliva. Preparing online lectures at home meant my puppy was curled on my lap, so she became the calming influence that students needed in a time of disruption, appearing on screen to provide a sense of normalcy and a connection to a brighter time.

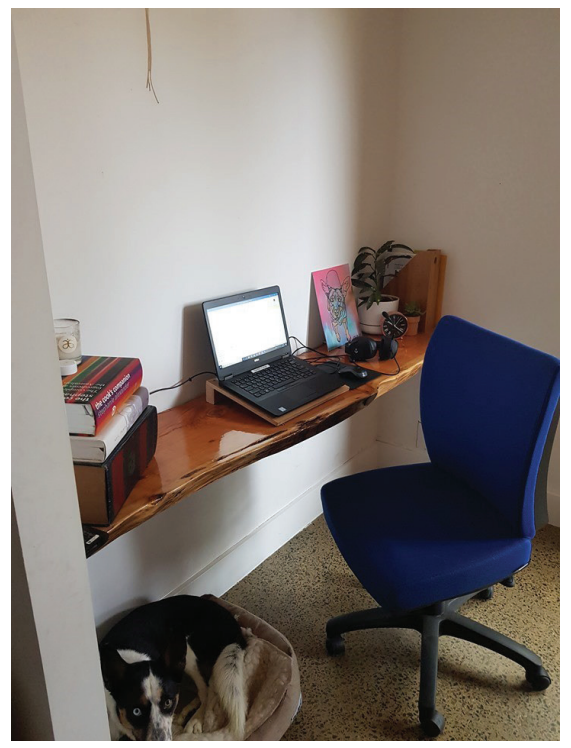

The next day was spent planning what teaching the unit online could and would look like. Armed with an iPad, tripod, Go-Pro, and laptop we set out to film the practical activities that the students were scheduled to complete throughout the semester. Take after take, we captured the experiences we hoped to share with our students. Using micropipettes, electrophoresis tanks, blood typing, and more, we recorded in detail each aspect of the laboratory experience. In less than two days, we had all the footage needed to develop virtual practicals. We moved swiftly, not knowing when the university would no longer be accessible to staff. Late nights were spent designing and creating virtual simulation activities that could replace a portion 
of the practical activities usually performed in the laboratory and tutorials. Simulations were created using Articulate Storyline 3 and developed around existing practical experimental data. Instead of students designing and carrying out their own experiments in class, we created a virtual scenario where they could manipulate criteria and record the resulting output. Students were able to complete the simulation at their own pace, from the safety of home and continue to record experimental data in a laboratory notebook. To support the interpretation of data and continue the completion of a traditional laboratory notebook, students then met with an academic teaching member for one hour to discuss the results and interpretation using the virtual platform Collaborate supported through the LMS.

\section{Deploying Expertise}

As a teaching specialist with formal qualifications in both science and education, part of my role is supporting other academics in the development of innovative teaching materials. Therefore, I was called upon to assist in the transition to online learning where possible. Alongside redeveloping my own teaching resources, I met with others to discuss how they could meet their learning outcomes in this new environment. Existing laboratory designs were reviewed and reimagined, tutorials reconfigured and held online. This problem was not unique to higher education. Secondary school teachers were also shifting their curricula online and were keen to connect and gather ideas to deploy in their own virtual classrooms. Academic staff were called upon to provide short training sessions in moving lessons online, with tips and tricks for keeping students engaged in learning. As educators, we have both an opportunity and an obligation to support our students and colleagues to continue learning and teaching. Through innovative practices, we have been able to provide a supportive learning environment using workable solutions to keep students and staff engaged and connected to a vibrant and supportive community that will help each other move through these challenging times.

\section{Consequences for Staff and Students}

The sudden shift to online teaching will not be easily undone. Perhaps it is time to end the traditional lecture and this may be the catalyst. There is much evidence to show that information delivery is limited by student concentration (Arvanitakis, 2014). Therefore, in a lecture theatre setting, I present material in short sections, interspersed with interactive and engaging problem-solving group-work tasks keeping students active and engaged with the content. The use of a tossable microphone enables the large group of students to share ideas and understanding, while allowing for a recorded option for those unable to attend face-toface classes. It is possible that the transition to the online recorded lecture may emulate this experience without the face-to-face component. However, practical experiences are an integral part of Biology teaching and learning, with many educators linking the practical experiences to improved content understanding as students explore tricky concepts in the laboratory (Hamzat, Bello, and Abimbola, 2017). Field and laboratory-based learning provides unique conceptual and technical experiences that are essential for the discipline (Fleischner, Espinoza, Gerrish, Greene, Kimmerer, Lacey, Pace, Parrish, Swain, Trombulak, and Weisberg, 2017). With the massification of tertiary institutions, there has been a recent shift towards the development of laboratory spaces intended to accommodate large groups of students designing and carrying out investigative research. At Flinders University, undergraduate laboratories accommodate 100 students and five teaching staff. Additionally, rather than traditional recipe-based experiments students design and direct their own experiments known as inquiry-based practicals (Smallhorn, Young, Hunter, and Burke da Silva, 2015). These experiences rely on students troubleshooting and repeating failed experiments then analyzing genuine data sets that they have collected themselves, resulting in an authentic research experience. This has been difficult to replicate in the virtual environment.

With many students unable to return to classes, locked out through closed borders, teaching must be adapted to enable various forms of student engagement. For the foreseeable future educators may be in the position of delivering both face-to-face where and when it is safe to 
do so, alongside a virtual program. Whilst this may be possible to provide in the short-term, I worry about the sustainability of this model into the future. I am tired. I see educators around me exhausted as they design curricula and deliver in new and innovative ways. I fear that this will be the new norm, as we are expected to continue delivery in a variety of modes to increase the availability of our courses to students around the globe to recoup what we can from the loss to international revenue sources. However, this duality is not sustainable. Educators cannot continue to perform under the current stresses of dual modes of delivery for an extended period. As educators, we have risen to the unique challenge posed by COVID-19, but to achieve the best possible outcomes for our students, careful thought is required in moving forward to manage both staff and student well-being. Educators have provided outstanding contributions at a significant cost to other academic work, and time will tell just how damaging this will be to the future of education research.

\section{Panic Learning in Physics (Or, Dis/ordered Ramblings from an Overstretched and Traumatized Mind - Jamie)}

\section{The Pre-COVID plan}

Physics 1A (real name PHYS1101 Fundamental Physics I) is perhaps the most challenging topic for a Physics academic to coordinate. For the teaching team, it is about coping with a group of commencing first year students with a wide range of backgrounds and skillsets, each of whom are embarking on one of many pathways and attempting - in one semester - to ensure they all face forward with a common, normalized disciplinary literacy that is equivalent to year 12 level physics (with some extensions thrown into the mix), so that they are prepared and ready to tackle first-year university physics with unfamiliar material in Physics 1B. This is, in its truest form, teaching for learning in both form and content. The attention to form requires distinctive modes of delivery and engagement and tropes of immersion and thinking. These are achieved by spending concentrated, ordered time in the learning environment. The content, which, when properly scaffolded, can be more usefully described as 'disciplinary literacy,' includes the themes, ideas, expertise, information literacy, and filters that each student needs to develop. These need to become deployable by the student, so that they know how to differentiate between sources of information, to discriminate between the valuable and the valueless, identify the invaluable, and then expertly apply their knowledge towards new form and content. This applies broadly, whether in learning or tackling real-world problems, or simply navigating and making sensible decisions in their daily lives. Put another way, educators start from their expertise and apply educational philosophy, recognized andragogical practices and information, digital and disciplinary literacy to inform their educational design and approach. Implementing the design involves the deployment of multimodal forms of delivery to achieve the learning objectives, which are about enhancing the disciplinary literacy of learners.

Physics $1 \mathrm{~A}$ is designed as a 13 -week program that continually and systematically develops these capacities in the student. Precision in the melding of form and content - andragogy and information - is a necessity. It is tough teaching and tougher learning. The learning environment has been very carefully constructed, with expectations set firmly in place, but also underpinned with support mechanisms that enable each student to thrive. This is particularly important with commencing first-year students. They need to transition into university life, which pose differing levels of challenges for each student but is crucial because they need to 'hit the ground running' and become stable learning 'machines.' This transition is by no means easy for students. University life is fast-paced and to the commencing student, it is like learning to ice-skate - to do it gracefully takes considerable familiarity, coordination, and confidence with one's balance.

Transitioning students need to make sure that they are familiar with resources and know-how to access them, but they also need to feel that they belong to their cohort. It is only after these aspects are established that students start developing their intellectual self-esteem, necessary for the effective development of learning and literacies. We start slowly because the personal 
and social transitions need due attention and require to be nurtured, but in our class we build momentum and move through complex concepts that quickly stretch the student's expertise. Added to this is the notion that I, as topic coordinator and lecturer, must create this integral learning experience in the first of many building blocks of programs that create a degree. Unlike many other disciplines, physics students mostly arrive straight from secondary school into the degree program. The role of the 'teacher' in the eyes of students carries assumptions from school that can be unproductive in universities. My role is to highlight what the students are required to learn. The responsibility for each student's learning, one that is usually associated with 'the teacher,' now lies firmly on their shoulders rather than mine. My role is transformed from that of a teacher to that of an educational designer who provides environments that maximize the potential for learning. I then implement this design, as a facilitator, tour guide, and mentor. However, one of my core actions in meeting these responsibilities lies in guiding students, managing their expectations and keeping them facing forwards, while reinforcing this message. The first two weeks of semester one in 2020 commenced in a regular manner with all of these notions in mind.

COVID and the imminent shutdown became real in week 2 of semester 1 . Week 2 . Consider that for a moment. A first-year student needs time to transition to University life - do they have a clear sense of what 'normal' university life entails at the end of week 2 of their very first semester? Lectures in week 3 were delivered online and my last face-to-face class was during a workshop on Friday of week 3, a class in which the students work on problems in groups and are required to submit a group assessment piece. Undergraduates were to be off-campus from week 4 and my colleague would be taking over lecturing the class, but I had the presence of mind to trial the online Collaborate environment in our learning management system with the students while still in a face-to-face setting. It was a truly authentic and prescient trial. I declared to the students that this was scientific experimentation in the truest sense. I was open and honest with them. This was new for me. This was new for them. We would become familiar with this interface together. Then for the next two weeks I remained engaged as topic coordinator and facilitator because we have laboratory classes in odd-numbered weeks and they were my responsibility, but additionally, I would return to lecturing them again in week 6 . I wanted to remain connected and monitor their experiences to remain aware of the 'new normal' for them - the learning environment to which they became familiar and accustomed, so that I might maintain consistency for them.

I used the time well. At home, I set up my office with all of the equipment needed to have a functioning online presence that is geared for teaching, capable of meeting with individuals and large groups of people. This equipment was not supplied by the university. The assumption was that domestic technology would be able to manage the requirements of online teaching. Considering the history of broadband internet roll-out in Australia, this was incorrect. But further, to manage the multimodal recording and narrowcasting necessary for lectures, workshops, and labs, conventional domestic technology for my home office was not able to manage the load.

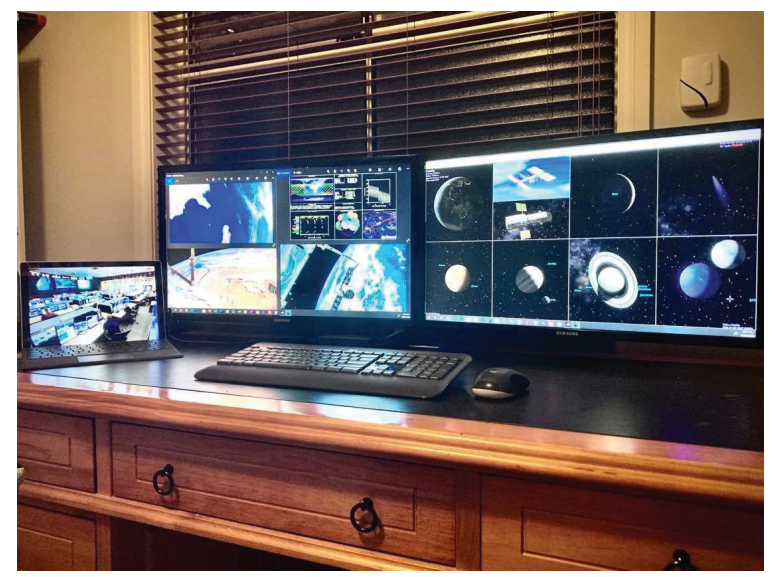


The system I established at home could manage the teaching and learning requirements of online delivery. The speed at which this set up was required - and the investment from my salary - raises a key question for the casualized, precariat academics that dominate teaching in the contemporary university. How could they subsidize the movement to online learning through a casualized salary?

\section{The Scale of My Input in the Decisions to Implement Online Learning}

After a College forum where we were given choices to consider - cancel if not needed, defer until later, or record demonstration videos - academics were consulted on our thoughts of 'How should labs operate if the campus becomes closed to students?' The preferred idea of the leadership was producing videos of the demonstrators performing measurements and then giving students data to analyze. The argument to justify this decision was, 'It works in Biology and Chemistry.' The generalizability of particular interfaces and modes of learning is an attempt to crush postFordist, bespoke, customized, and disciplinary-specific requirements, creating homogenization and Fordist learning. This is a confusion of standardization with standards.

My physics academic colleagues realized that such a system would not operate at first, secondor third-year level. We thought it best to defer the labs for now and not enable this mode of learning until COVID restrictions were lifted and ensure the students to complete the labs in an intensive mode. This strategy was also not ideal, due to the benefit of formative feedback between experiments, but this compromise was appropriate as hands-on skill development is integral to experimental physics training. Put more brutally, would you trust your body to surgery by someone who is confident of performing a procedure because she has seen it performed on video? Would you be a passenger in a plane where the pilot has never flown an actual aircraft but only watched a video of someone else flying one? I feel the same way about unleashing students with no experimental skills on the $\$ 1.2 \mathrm{M}$ electron microscope in my research laboratory. The idea of teaching via videoed demonstrations of experiments would be particularly undesirable in third-year classes, where students learn to become confident with complicated scientific apparatus and experimental thinking. To lose this scaffolding in the first year where literacy begins is profoundly problematic, to say the least.

Further, the academics who have to suddenly teach online had no experience or confidence with producing video and delivering online content. My topic was centered around student experiences and I was protective of the compromise in standards that this would impose. I admit that I may have been sensitive because over the past decade first-year physics has been the test-bed of first-year offerings, often forced to compromise its form and content in the name of innovation. I was satisfied with the decision to give students an incomplete grade until they could do the practical work but was mindful of the students being left to wander alone in the physics wilderness, so I sought to find a way to keep them engaged. I contemplated possibilities over that weekend, from a 'starting from scratch' educational design perspective. I asked, 'what can I do that will build disciplinary literacy in an authentic way within the frame of the new, forced mode of delivery that makes the best use of the digital platform?' My answer: I need to make the students spend time authentically engaged with born-digital material, but 'how can it be used most effectively to provide them with a program that meets the learning objectives while empowering them as learners?' Making them watch videos of someone else performing an experiment, then giving them data to analyze would be deeply disempowering.

A better use of their time would be to start developing computational literacy (a different means of putting theoretical concepts into practice) with Mathematica. Under the University's license, students can obtain an academic version that they can use on their personal device. I then designed an exercise that involved students and demonstrators engaging in a Collaborate online classroom, that would first develop 'familiarity' by demonstrating some examples from year 12-level mathematics that they would be surprised to see. Students could explore and build upon these examples within the online laboratory session to provide meaningful connections, and then apply these newfound skills to a homework exercise that they could complete 'open 
book style' to reinforce the key ideas and provide them with some 'ownership' of their newfound literacy. I designed a three-lab programme to scaffold the development of this disciplinary literacy. This alternate design was responsive to circumstance, created 'on the fly', developed and rolled out at the last moment. I sought feedback from all of the students, closely observed issues and challenges to that feedback and feed forward to be responsive, to continually improve the student experience.

Once I had developed my ideas to the point that I felt they were not just viable but a suitable solution, I 'managed up' by noting them to our TL leadership as a way of using the 'laboratory contact time' in a productive way. The following week, my Physics academic colleagues met with the leadership team to determine the approaches that would be used in 2 nd and 3 rd year level offerings to support student learning during the lockdown. I was teaching a class when this meeting was held in Week 4 and so missed it. However, I continued with my plan: students spending 'contact' time on the valuable and engaging tasks I had designed, developing disciplinary literacy that would be of benefit to them. In week 5 of semester the first Mathematica lab was implemented, with me involved in leading and supporting student learning and demonstrator literacy as necessary, despite this time not being in my workload. Developing lectures in a new, unfamiliar setting is always challenging, but to enact this process while changing laboratories for a rich, born-digital environment in the middle of teaching term, without adequate time to perfect it, presented an entirely new level of stress.

\section{What I was Forced to Do}

Two weeks after I started the process of replacing our laboratory experiments with Mathematica exercises, in the middle of week 6 I was informed by the leadership team to defer hands-on skill development in the laboratory. 'Incomplete grades' was suddenly not an option as the intent was to complete all students by the end of the semester. I was told to comply with the strategy and produce videos by recording demonstrators performing the hands-on activities in each lab and giving data to the students to analyze. As much as I vehemently disagree with the learning outcomes achieved via this approach, it was superior to not performing anything in the laboratory at all. My concern was that the Physics 1B laboratory program, which follows on from Physics 1A, possesses more complex tasks and occurs via an alternate mode. It is challengebased. It relies on familiarity and literacy in the laboratory that is only gained through performing the experiments of Physics 1A, which meant that completing the Mathematica program without including the experimental design and experience of the 'normal' lab program would make the laboratory experience for Physics 1B impossible for students to undertake and successfully complete. I have been in this position before and have taken the same stance and approach that I have always done, which is to make the best of the bad situation and try to provide the best possible experiences and outcomes that I can for the students, while upholding standards. As the Dean of Science that is ultimately my role, and it is one that I take quite seriously. Laboratory experience is intensely interactive and involves hand-eye-brain coordination. It is, by its very nature, an active learning environment. The experiments that are in the Physics 1A laboratory were designed to be particularly interactive and thought-provoking, utilizing multiple learning modes. Each experimental exercise begins with students observing eye-opening demonstrations of the 'theme' to capture their attention and interest; perform a conventional experiment where a systematic investigation with measurements is followed; a Mathematica simulation to demonstrate key dependencies of parameters that can be controlled/experimented in a mixed procedural and exploratory way - students tend to use this to produce 'nominal' or 'theoretical' data to compare with their measurements; then at the end if they complete the task, students get to 'play' with the demonstrations themselves and are encouraged to explain why they behave as they do with their new-found knowledge and understanding. This is considerably difficult to translate to an online setting and watching someone else move through this process does not replicate or address the learning outcomes because one does not authentically own their knowledge when they watch someone else perform the task. 


\section{Possible Consequences/Prophecies of Foreboding}

The primary consequence of these changes enacted through COVID is that students will not have achieved the goal of a 'normalized' year 12 level understanding of physics upon completion of Physics 1A. Students see online environments as asynchronous so that they can engage when it suits them, whereas face-to-face environments are live and synchronous. Coupled with that, there is a behavioural change with consequences for learning. Everything is recorded for student convenience. My second-year class on optics has several students that have not fronted to a live class all semester. Such a decision is made more ironic, considering that optics is about 'seeing' and being 'seen.' They clearly see no benefit in interacting with the lecturer and these courses in experimental physics are being treating like a reading course. The convenience of accessing the materials when it suits them - when they need to access material to perform an assessable task in a just-in-time fashion - clearly exceeds any impetus for live interaction. In contrast, commencing first-year students are less confident and want to remain inconspicuous at the best of times, but in this new environment, it is easier for them to 'skip classes' with the intention of 'catching-up' later. I always tell first-year students two truths:

- The habits you develop in the first year are carried throughout the whole course and possibly the rest of your life; and

- The road to (knowledge) hell is paved with good intentions.

Expertise is built in a manner very much like that of a pyramid where new concepts build and extend upon existing ones, knowledge gaps weaken and can even paralyze the capacity of the learner to absorb, digest, and understand them. From the perspective of the student, they will experience more angst and anxiety going forwards until these gaps are filled and they will have to do it for themselves without the disciplinary literacy to do it effectively. For final-year students, this will be less of an issue and they are likely to never fill these knowledge gaps unless they need to, being able to get by without - but first-year students will carry this impediment throughout their entire higher education. The angst and anxiety can only lead to an increase in the rate of failure and attrition and lead to reduced degree completion rates.

We must be mindful and alert to the factors that influence each student's attitude towards their learning. We all seem to have caught the COVID-19 disease whether we have actually had it or not and it has left us intellectually traumatized. Ordinarily, the notion that 'Ps get degrees' is a way of rendering the difficult challenge of success a safer prospect for students, but it is an unhealthy position and sets low standards. As students' progress, this is the biggest challenge for them. They need to aim much higher. If they do not alter this viewpoint, their future, professional selves will regret it later. This whole experience has provided students with a convenient excuse for lackluster or underperformance. I have encountered far more 'excuses' this semester from students fearlessly telling me what they are unable to do and all of the reasons why, without guilt, without responsibility. My fear is that it will foster a new cultural attitude of 'PTSD gets degrees' and I shudder at the notion of excuse-driven (un)learning. This latter behavior has been even more prevalent in the postgraduate research students, who have suffered the same intellectual paralysis due to the myriad of 'inconvenient possibilities that might occur due to the pandemic' even though our campus remained open for them and for research.

Coping with the transition to online learning environments without any prior experience or time to plan for effective actions has been challenging, but the transition back again had not been considered either. The assumption has been that it is simply an act of flicking a switch and 'normal' operations would quickly resume. As restrictions started to become lifted, staff were 'forced' back onto campus in weeks 10 and 11 of the semester, the transition back has been challenging as well. The decision has been made to keep all classes online for the remainder of semester, which is a position that I wholeheartedly agree with as 'the game' has already been changed twice for the students in my first-year class. An unintended consequence though is that I have come to discover that my home office is now better equipped than my work office for my 
online presence and, in particular, for delivering online classes.

\section{A Conclusion in a Circle (Tara)}

Circuit, short-circuit; there is no circus without a circle.

Paul Virilio (2012)

Mobility studies, alongside popular memory studies, remain the Andrew Ridgely of academic life. These anti/post-disciplines should have been expansive, propulsive and interventionist, enabling research into the political economy, higher education, and theorizations of teaching and learning. Instead, they remain discarded, marginalized, and a mere footnote to easier, more applicable scholarship. Paul Virilio is similar. He was never as popular as Jean Baudrillard. He was never as weird as Jacques Lacan. He did not kill a close relation, like Louis Althusser. He did not wear leather as effectively as Michel Foucault. Instead, he developed a career close to the flame of the French intellectual crucible, but was always socially distanced. His bunker archaeology prepared us for COVID, over a half a century ahead of the threat. Yet also, Paul Virilio's unusual and complex friendship with Baudrillard provides a model for this article, and indeed a revisioned university. Upon Baudrillard's death in 2007, Virilio spoke at the European Graduate School in La Rochelle in France.

The big difference between Jean and me is that he worked on simulation and I worked on substitution...I would like to relate a small anecdote about Baudrillard and simulation and substitution. When we found ourselves at the Revue Travers, I had just finished my photographic campaign, which took ten years, on the wall of the Atlantic. Baudrillard hated photography at the time. I went to the Revue Travers because before, in the Revue de L'esprit, they didn't have photos or images. At the Revue Travers, I could publish my photos and I told the revue, "I am coming". When I saw Baudrillard, he said "Tisk, tisk, tisk". And now he is dead and I am still alive...It's been quite a long time now since I have stopped taking photos, but he began taking photos. He even finally became a photographer. This is typical in our movement (Virilio, 2009: 68-70).

With Virilio's death following Baudrillard by a decade, the pendulum-swing between simulation and substitution has only increased in speed. COVID triggered panic learning, panic teaching and the claustropolitan university. Simulations of laboratory classes dueled with substitutions of behaviors, actions, activities, assessment, and rubrics. Simulations of face-to-face classrooms were a cut-price outcome for a lack of professional development. Very quickly, different modes of 'lectures' emerged. The substitution created a cascade of options and alternatives. Borndigital 'lectures' are different from their analog companion. Those differences - summoned in a moment of panic learning in a pandemic - are instructive.

This current article is unusual. Like Baudrillard and Virilio's friendship, rarely do cultural studies, physics, and biological science academics collaborate, speak and write together. Silos, gatekeepers and tightly bounded disciplinary literacies block productive, disturbing conversations about knowledge, teaching, learning and research. Yet in a time of panic learning, odd, unstable and difficult conversations are necessary and powerful. Tight and considered relationships between teaching and research are required, contextualized by higher education studies. This article was written by award-winning teachers, who are also active and engaged researchers. There is profound value in aligning once more - in a time of teaching specialists, educationfocused and research-only academics - a return to the discussion of university scholarship, and the tight alignments and dialogues between teaching and research.

What is not needed at this point in university history is a critique of the intellectual. Unfortunately, the Australian humanities disciplines - the aging Cinderella who never had a chance to go to the ball and remains cleaning the fireplace of our universities - are in a death 
spiral at the end of the world. Defensive, paranoid and resentful of international colleagues, University presses are closing, humanities journals are ceasing publication, and senior academics at elite institutions are summoning old and tired ideas confirming the irrelevance of intellectuals in difficult times. For example, in the final issue of the Cultural Studies Review in 2019, the editors published a failed referee report that blocked the journal from gaining international funding. They Australian editors attacked this referee for their commentary, rather than seeing the deep truth expressed within it. The referee stated,

The most recent issue ... exemplifies the strengths and weaknesses of the journal ... I think the journal is the Meaghan Morris Motel ... This is a very Australian journal- very, very local even in its efforts to reach outwards. If I want to know what Australians are thinking about things, I would consult it. But in many ways it feels like a different planet than my own and I don't think I would read it regularly ... This is an Australian journal. I had to sit down and ask myself, as someone who has run a Cultural Studies program, who considers herself to be in the field, what journals do I read regularly? What I don't do is read regularly work in the journals that claim to offer research from cultural studies as a distinct field ... Australia is a big country and there are really smart and interesting people who work there. But the journal has a very Australian profile (anonymous reviewer in Healy and Schlunke, 2019, 3)

There is a lesson to be learned from this review. The lesson is not the anti-Australian nature of US-based publishing. It has never been easier to find an audience for Australian research in the United States. Our article in Fast Capitalism, written by three Australian scholars, confirms this truth. The point is that Meaghan Morris was a minor scholar from a minor nation who published an interesting book at the point that 'French theory' was being translated into English. The Pirate's Fiancée (Morris, 1988) was published over thirty years ago and has not dated well. For minor names and minor publications to be commemorated and celebrated beyond intellectual generosity and legacy content serves to anchor scholarship to a mediocre past. This book remains a metaphor for not only Australian cultural studies, but the Australian humanities more generally. Decades of under or non-existent governmental funding, culture wars, bastardized importation of powerful paradigms like creative industries, and mediocre scholars' gatekeeping and limiting the boundaries of disciplines through funding agencies and the ERA (Excellence in Research Australia) have created a terminal inwardness. When confronted by this truth of insularity and international disconnection in a referee report for the Cultural Studies Review, the editors merely replied,

The myopic arrogance of such an account is the uniquely parochial preserve of (some) American academics who would no doubt chastise the activists on the streets of Hong Kong and Beirut as indulging in very, very local activity of very, very limited value. The less we have to engage with such people, the better (Healy and Schlunke, 2019, 3).

Sigh. Comparing an Australian cultural studies academic journal to the political activism on the streets of Hong Kong and Beirut demonstrates the accuracy of the referee's judgment. The final sentence confirms the bitchiness, insularity and self-congratulatory nonsense that are now the marinade of the Australian humanities.

It is from this font and context that Ghassan Hage, from the University of Melbourne, wrote of Bourdieu - without a reference - and cited only three scholars in a refereed article on COVID and our universities. Of those three scholars - Ahmed (2019), Hage (2017), and Levy-Bruhl one was a self-citation. The complex and intricate literature from international higher education studies in the last twenty years remains unused and unreferenced in a discussion of politics, universities, and intellectual life. A refereed article in the European Journal of Cultural Studies was accepted with three references. Further, the very definition of politics is retrograde and problematic in the article: 
And yet, because, in the face of a pandemic, there is something true in the statement that 'now is not the time for politics,' engaging in intellectual and political critique cannot and should not be treated as a facile endeavour. A lack of awareness that one is dwelling amid such a contradictory situation that is at once hyper- and a-political is bound to create that very annoying and useless pontificator we began with. I am assuming that a critical intellectual cares not only about being right but about being listened to. Strategic questions of tone, of timing, of what to say and not to say, and of how much to insist, all become particularly important (2020, 2-3).

Such platitudes, caveats, and codicils seem quaint, a residue of politics of an earlier and better time. From an (online) classroom at the end of the world, with casualized academics dumped like garbage out of a car window and permanent staff rendered voluntarily and involuntarily redundant, with tough regional and rural universities crushed through the short-sighted management of budgets by inexperienced Vice Chancellors who are taking country towns down with them, courage is required. Pondering 'how much to insist' is a phrase and behavior more suited to a regency drama than the tough pandemic politics of panic learning. Not surprisingly, Hage - without references to higher education studies - reverts back to the personal.

That is why people telling me how my teaching or my writing has positively affected their lives has been and continues to be immensely sustaining. And even though I have had enough experiences of students and readers who have given me positive feedback about my work to feel confident and good about its effect on people, I know that it is not beyond me to dwell in negative chatter. The figure of the useless academic continues to haunt me $(2020,3)$.

For those of us who do not have the privilege of feeling good about ourselves through 'positive feedback,' 'negative chatter' is the least of our concerns. Beyond the self, what will happen to the higher education workforce? What will happen to these under-prepared first-year students, who then enter second year - under-prepared from their first year - and will then enter an honors and then doctoral program? Are we satisfied that first-year students can 'watch' a lab and gain a substitution for the simulacrum for the analog experience? Yes, the humanities can fixate on an individual academic feeling good about their personal teaching and writing. But the intellectual - without the mitigating adjectives of 'critical' or 'public' - has a singular and first responsibility. We must arch beyond ourselves. Beyond our feelings. Experiences are important. But they are the first step and stage in knowledge.

This article has modeled and summoned, not the "haunting figure of the useless academic" (Hage 2020), but the angry, exhausted, worried, charged, agitated, up-for-a-scrag-fight scholar who welcomes radical critique from radically different disciplines, slam cuts teaching and research, and connects the daily experience of scholarship with the wider positioning of universities in a world that is falling away below our feet. This article has not summoned a critical intellectual or public intellectual. Instead, we activate the sweaty scholar on the move, panicked by under-resourced, under-theorized change, frightened for the future, but staunchly occupying the present. The time for petit-bourgeois chatter has concluded. This is the time for the activist, angry academic, the teacher theorist negotiating the end of the world. The time for hand-wringing about why the humanities are demeaned and marginalized is over. It is time to build the partnerships between the humanities and the sciences, rather than sit in self-absorbed, self-entitled silos. Summon anger. Summon rage. Call out the decline in standards of teaching and learning, rather than fixate on personal discomfort. Activate a brutalizing discussion of the academic workplace and the exploitations activated every day, by supposedly left-leaning 'managers.' An academic is only useless if they choose to be. To summon an echo of Irvine Welsh - we choose difference. We choose disquiet. We choose despair. We choose activism. We choose outwardness. We choose internationalization. We choose heat and passion. We could choose being useless. But why would anyone do that? That is not why people choose the life of an academic. 


\section{References}

Ahmed, S. (2019) What's the use: on the uses of use. Durham: Duke University Press.

Aronowitz, S. (2000) The Knowledge Factory. New York: Beacon.

Arvanitakis, J. (2014). Massification and the large lecture theatre: from panic to excitement. Higher Education, $67(6), 735-745$.

Baudrillard, J. (2009) Why Hasn't Everything Already Disappeared? London, New York and Calcutta: Seagull Press.

Baudrillard, J. (2007) In the Shadow of the Silent Majorities. Los Angeles: Semiotext(e).

Baudrillard, J. (2005a) The Intelligence of Evil or the Lucidity Pact. Cambridge: Polity.

Baudrillard, J. (2005b) Cool Memories V. Cambridge: Polity.

Baudrillard, J. (2004) The Spirit of Terrorism. London and New York: Verso.

Baudrillard, J. and Guilliame, M. (2008) Radical Alterity. Los Angeles: Semiotext(e).

Baudrillard, J. and Nouvel, J. (2002) The Singular Objects of Architecture. Minneapolis: University of Minnesota Press.

Baudrillard, J. (1993) Symbolic Exchange and Death. London: Sage.

Bishop, R. (ed) (2009) Baudrillard Now: Current Perspectives in Baudrillard Studies. Cambridge: Polity.

Brabazon, T. (2002) Digital Hemlock: Internet education and the poisoning of teaching. Sydney: UNSW Press.

Brabazon, T. (2002) Ladies Who Lunge: Celebrating Difficult Women. Sydney: University of New South Wales Press.
Brabazon, T. (2000) Tracking the Jack: A retracing of the Antipodes. Sydney: University of New South Wales Press.

Brabazon, T. (2011) "We've spent too much money to go back now: credit crunched learning and the future of literacy," e-Learning, 8.4: http://www.wwwords.co.uk/ elea/content/pdfs/8/issue8_4.asp

Brabazon, T. (2013) Digital Dieting. Aldershot: Ashgate.

Clarke, D., Doel, M., Merrin, W., and Smith, R. (eds) (2008) Jean Baudrillard: Fatal Theories. London: Routledge.

Coulter, G. (2012) Jean Baudrillard, From the Ocean to the Desert: The Poetics of Radicality. Florida: Intertheory Press.

Farrelly, E. (2020) 'The decline of universities, where students are customers and academics itinerant workers', The Age, May 30: https://www.theage.com. $\mathrm{au} /$ national/the-decline-of-universities-where-students-are-customers-and-academics-itinerant-workers-20200528-p54xbd.html?fbclid=IwAR3SjAdkTkGn9q8IE6NnKaDeHy9tjdNly8uBRfIHoOMssobpUe1dSnjvVc4

Fleischner, T.L., Espinoza, R.E., Gerrish, G.A., Greene, H.W., Kimmerer, R.W., Lacey, E.A., Pace, S., Parrish, J.K., Swain, H.M., Trombulak, S.C. and Weisberg, S., 2017. Teaching biology in the field: importance, challenges, and solutions. BioScience, 67(6), pp.558-567.

Gane, M. (1991) Baudrillard: Critical and Fatal Theory. London: Routledge.

Hage, G. (2020) 'The haunting figure of the useless academic: Critical thinking in coronavirus time', European Journal of Cultural Studies, DOI: $10.1177 / 1367549420926182$.

Hage, G. (2017) Is racism an environmental threat? New York: Polity Press. 
Hamzat, A., Bello, G. and Abimbola, I.O., 2017. Effects of computer animation instructional package on students' achievement in practical biology. Cypriot Journal of Educational Sciences, 12(4), pp.218-227.

Healy, C and Schlunke, K. (2019) 'The final issue Cultural Studies Review', Cultural Studies Review, 25.2: 1-7.

Henebery, B. (2020) 'Regional universities at risk of big job losses', The Educator, May 27: https://www.theedicatoronline.com/he/news/ regional-universities-at-risk-of-big-job-losses

Houlden, S. and Veletsianos, G. (2020) 'Coronavirus pushes universities to switch to online classes - but are they ready? The Conversation: http://theconversation. com/coronavirus-pushes-universities-to-switch-to-online-classes-but-are-they-ready- 132738

Levy-Bruhl, L. (1985) How natives think. Princeton: Princeton University Press.

Marshman, I. and Larkins, F. (2020) 'Modelling Individual Australian Universities Resilience in Managing Overseas Student Revenue Losses from the COVID-19 Pandemic,' Centre for the Study of Higher Education, https://melbourne-cshe.unimelb.edu. au/__data/assets/pdf_file/0009/3392469/AustralianUniversities-COVID-19-Financial-Management.pdf ?fbclid=IwAR2dDP10xAYU835QOkEhkXxKmMV-9BV9bHn5AvGLwCUlwlH71qLI0e3kgzs

Morris, M. (1988) The Pirate's Fiancée: Feminism, Reading, Postmodernism. London: Verso.

Pragholapati, A. (2020) 'Covid-19 impact on students', OSF: https://osf.io/xm9w4/

Redhead, S. (2011) We Have Never Been Postmodern: Theory at the Speed of Light. Edinburgh: Edinburgh University Press.

Redhead, S. (ed) (2008) The Jean Baudrillard Reader. Edinburgh: Edinburgh University Press/New York: Columbia University Press, European Perspectives Series.

Redhead, S. (2004a) Paul Virilio: Theorist for an Accelerated Culture. Edinburgh: Edinburgh University Press/Toronto and Buffalo: University of Toronto Press.
Redhead, S. (ed) (2004b) The Paul Virilio Reader. Edinburgh: Edinburgh University Press/New York: Columbia University Press, European Perspectives Series.

Smallhorn, M., Young, J., Hunter, N. and Burke da Silva, K., 2015. Inquiry-based learning to improve student engagement in a large first year topic. Student Success, 6(2), pp.65-72.

Smith, R., Clarke, D. and Doel, M. (2011) 'Baudrillard Redux: Antidotes to Integral Reality', Cultural-Politics 7 (3) 325-337.

Virilio, P. (2012) The Great Accelerator. Cambridge: Polity.

Virilio, P. (2010a) The Futurism of the Instant: Stop-Eject. Cambridge: Polity.

Virilio, P. (2010b) The University of Disaster. Cambridge: Polity.

Virilio, P. (2009a) The Aesthetics of Disappearance. Los Angeles: Semiotext(e).

Virilio, P. (2009b) Grey Ecology. New York: Atropos.

Virilio, P. (2009c) Bunker Archaeology. New York: Princeton Architectural Press.

Virilio, P. (2007a) Art as Far as The Eye Can See. Oxford: Berg.

Virilio, P. (2007b) The Original Accident. Cambridge: Polity.

Virilio, P. (2005) City of Panic. Oxford: Berg.

Virilio, P. (2002) Ground Zero. London: Verso.

Virilio, P. and Richard, B. (2012) The Administration of Fear. Los Angeles: Semiotext(e).

Wuhan City Health Committee (2019) Wuhan Municipal Health and Health Commission's briefing on the current pneumonia epidemic situation in our city 2019, http://wjw.wuhan.gov.cn/front/web/ showDetail/2019123108989 
